\title{
Millî Eğitim Bakanlığına Bağlı Kurum Yöneticilerinin İlahiyat Fakültesi Mezunlarından Beklentileri: Erzincan İli Örneği
}

\section{Expectations of Institutional Administrators Working in the Ministry of National Education from the Graduates of the Faculty of Theology: The Sample of Erzincan}

\section{Dr. Öğr. Üyesi M. Zeki GÖKSU}

Erzincan Binali Yıldırım Üniversitesi, İlahiyat Fakültesi

Asst. Prof., Erzincan Binali Yıldırım University, Faculty of Thology, Erzincan, Turkey.

mzekigoksu@hotmail.com D0000-0003-0875-2226

\section{Hülya GÜVEN}

Erzincan Binali Yıldırım Üniversitesi, Sosyal Bilimler Enstitüsü

MBA Student, Erzincan Binali Yıldırım University, Institute of Social Sciences, Erzincan, Turkey.

\begin{tabular}{lcr}
\multicolumn{2}{c}{ Makale Bilgisi / Article Information } & \\
& Makale Türü / Article Type Araştırma Makalesi / Research Article & Yayın Tarihi / Published \\
Geliş Tarihi / Received & Kabul Tarihi / Accepted & 23 Eylül / September 2021 \\
22 Haziran / June 2021 & 23 Eylül / September 2021
\end{tabular}

Atıf Bilgisi / Cite as:

Göksu, M. Zeki- Güven, Hülya. “Millî Eğitim Bakanlığına Bağlı Kurum Yöneticilerinin İlahiyat Fakültesi Mezunlarından Beklentileri: Erzincan İli Örneği”, Eskişehir Osmangazi Üniversitesi İlahiyat Fakültesi Dergisi 8/2 (Eylül 2021), $258-283$.

http://doi.org/1051702/esoguifd.9561109

İntihal / Plagiarism: Bu makale, en az iki hakem tarafından incelenmiş ve intihal içermediği teyit edilmiştir. / This article has been reviewed by least two referees and scanned via a plagiarism software.

Copyright (c) Published by Eskişehir Osmangazi Üniversitesi, İlahiyat Fakültesi /Eskișehir Osmangazi University, Faculty of Theology Bütün hakları saklıdır. / All right reserved. https://dergipark.org.tr/tr/pub/esoguifd

CC BY-NC 4.0 This paper is licensed under a Creative Commons Attribution-NonCommercial License

Etik Beyanı / Ethical Statement: Bu çalışmanın hazırlanma sürecinde bilimsel ve etik ilkelere uyulduğu, yararlanılan tüm çalışmaların kaynakçada belirtildiği ve bu araştırmanın desteklenmesi için herhangi bir dış fon almadıkları yazar tarafından beyan olunur / It is declared by the author that scientific and ethical principles have been followed while carrying out and writing this study; that all the sources used have been properly cited; that no external funding was received in support of the research. 


\section{Millî Eğitim Bakanlığına Bağlı Kurum Yöneticilerinin İlahiyat Fakültesi Mezunlarından Beklentileri: Erzincan İli Örneği}

Öz • Amaç, Erzincan İl Milli Eğitim Müdürlüğü Yöneticileri ile aynı müdürlüğe bağlı olarak görev yapan Okul yöneticilerinin, kurumlarında görev yapan ilahiyat fakültesi mezunu din kültürü ahlak bilgisi öğretmenlerinden memnuniyet düzeylerini ve beklentilerini tespit etmektir. Veriler 2019-2020 eğitim - öğretim yılında Erzincan İl Milli Eğitim Müdürlüğünde görev yapan toplam 73 kurum yöneticisinden elde edilmiştir. Veri toplama aracı olarak, Erzincan Binali Yıldırım Üniversitesi dış paydaş anketi kullanılmıştır. Bulgular, ilahiyat fakültesi mezunlarına kazandırılan mesleki becerilerin yeterli olduğu, Erzincan İl Milli Eğitim Müdürlüğü kurum yöneticilerinin kurumlarında çalışan DKAB öğretmenlerinden memnun oldukları ve beklentilerini karşıladığını göstermektedir.

Anahtar Kelimeler: Din Eğitimi, MEB, İlahiyat Fakültesi, Beklenti, Memnuniyet.

Expectations of Institutional Administrators Working in the Ministry of National Education from the Graduates of the Faculty of Theology: The Sample of Erzincan

Abstract ? The aim is to determine the level of satisfaction and expectations of the school administrators, who work under the same directorate as the directors of Erzincan Provincial Directorate of National Education, from the religious culture and ethics teachers who are graduates of the faculty of theology in their institutions. The data were obtained from a total of 73 institution administrators working in Erzincan Provincial Directorate of National Education in the 2019-2020 academic year. Erzincan Binali Yıldırım University external stakeholder survey was used as a means of collecting data. As a result, it shows that the vocational skills gained to the graduates of the faculty of theology are sufficient, the institution administrators of Erzincan Provincial Directorate of National Education are satisfied with the teachers working in their institutions and meet their expectations.

Keywords: Religious Education, Ministry of National Education, Faculty of Theology, Expectation, Satisfaction. 


\section{Giriş}

Eğitim, toplumların değişiminde ve gelişiminde en önemli faktörlerden biridir. İnsanoğlunun eğitimi ilk olarak anne karnında başlar ve hayatının sonuna kadar devam eden bu eğitim ve öğretim süreci içinde kendini şekillendirmektedir. Birey ilk önce yaşadığı çevre ve toplum hakkında bilgi sahibi olurken daha sonra farklı çevre ve kültürler hakkında bilgi sahibi olmaktadır. ${ }^{1}$ Öğrenmeye ve öğretmeye açık olan birey bazen öğreten durumunda iken bazen de öğrenen durumunda hayatını devam ettirmektedir. ${ }^{2}$ Kişinin çevresinden ve kültüründen öğrendiği tutum ve davranışlar, hayatına yön verirken ayrıca ilk örgün öğretimle başlayan eğitim hayatı ve sonrasında üniversite ile devam eden bir öğrenme süreci de kişinin hayatını fazlasıyla etkilemektedir. ${ }^{3}$ Bu etki bireyle sınırlı değildir. Eğitim süreci içerisinde insanlar bilgilendikçe bulundukları çevreyi ve toplumu etkilemekte ve onları değişime sürüklemektedir. ${ }^{4}$

Küresel dünya açısından eğitim, beşerî ve toplumsal ihtiyaçların karşılanması için önemli bir araçtır. Geçmişten günümüze kadar her toplumun kendi içinde eğitim kurumları ve bu eğitim kurumları için belirlenmiş eğitim programları bulunmaktadır. ${ }^{5}$ Eğitimle ilgili yapılan tüm bu çalışmalar insanları ve toplumları farkı amaçlar ile geliştirmek için yapılmıştır. Eğitimin temel amacı alanında kendini daha geliştirmiş bilgili, olgun ve nitelikli insan yetiştirmektir. ${ }^{6}$ Bu ihtiyaçtan ötürü her toplum kendi kültürel değerleri, toplumsal ve bireysel ihtiyaçlarını ele alarak ve evrensel değişimleri de göz önünde bulundurarak bir eğitim modeli oluşturmuştur. Eğitim modelleri topluma ve bireye dönük ihtiyaç ve yönelimlerin yanı sıra bireylerin ilgi alanını, ihtiyaç ve beklentilerini göz önünde bulundurularak hazırlanmaya çalışılmıştır. Ülkemizde de belli eğitim modellerine göre bireyler okullarda eğitim almaktadır. ${ }^{7}$ Alınan bu eğitimler doğrultusunda bireylerden beklenilen, aldıkları eğitimleri topluma ve yaşantılarına iyi bir düzeyde yansıtabilmeleridir.

\footnotetext{
${ }^{1}$ Halis Ayhan, “İlahiyat Fakültesi”, Dini Araştırmalar Dergisi 17 (1999), 19-39.

${ }^{2}$ Ali Özenç, "Son Sınıf Öğrencilerine Göre Beklentileri Karşılama ve Mesleki Hayata Hazırlamada İlahiyat Fakültelerinde Eğitim (Dicle Üniversitesi Örneği)”, International Journal of Kurdish Studies 3/1 (25 Ocak 2017), 1-30.

${ }^{3}$ Fatma Varış, “Üniversitenin Değişen Fonksiyonu ve Birkaç Sorun”, Ankara Üniversitesi Eğitim Bilimleri Fakültesi Dergisi 7/1 (12 Eylül 2019), 345-360.

${ }^{4}$ Ejder Okumuş, “illahiyat Fakültesi Öğrencilerinin Problemleri - Dicle Üniversitesi Örneği -", Değerler Eğitimi Dergisi 5/13 (01 Haziran 2007), 59-94.

${ }^{5}$ Adem Korukçu, “İlahiyat Fakültesi Son Sınıf Öğrencilerinin Yaygın Din Eğitimine Bakışları”, Değerler Eğitimi Dergisi 9/21 (01 Haziran 2011), 55-97.

${ }^{6}$ Mehmet Korkmaz, “ílahiyat Fakültelerinin Yaygın Din Eğitimi Yeterlikleri: Eğitim-Öğretim Alanı”, Değerler Eğitimi Dergisi 10/24 (01 Aralık 2012), 127-146.

${ }^{7}$ Cemil Osmanoglu - Mehmet Korkmaz, “Öğrencilerine Göre İdeal İlahiyat Fakültesi Öğrencisinin Nitelikleri ve Bunların İlahiyat Eğitimiyle İlişkisi”, Değerler Eğitimi Dergisi 16/36 (2018), 119-178.
} 
Ülkemizde çok çeşitli eğitim alanları bulunmaktadır. Toplumun bir kısmına göre eğitimin temel konusu olarak sayılabilecek "din eğitimi" kavramı da bu eğitim alanlarından biridir. Din eğitimi ilk olarak anne ve baba tarafından verilirken daha sonra çevre ve eğitim kurumları tarafından verilmektedir. Kişi ilkokul, ortaokul ve lise hayatında din kültürü ve ahlak bilgisi dersi kapsamında dinî ve ahlaki konularda bilgi sahibi olur. Ayrıca genel ortaokul ve liseler dışında tercihe bağlı olarak daha kapsamlı bir din eğitimi almak isteyen kişiler için ise imam hatip ortaokulları ve liselerinde eğitim alma imkanına sahiptir. Bu okullarda eğitim veren DKAB öğretmenleri profesyonel olarak mesleki uzmanlıklarını öğrencilerine aktarmaktadır. Din eğitimi alanında uzman kişiler yetiştirerek Millî Eğitim Bakanlığına öğretmen yetiştiren İslami İlimler/İlahiyat Fakülteleri bu anlamda günümüzün en önemli kurumları olarak örnek verilebilir. ${ }^{8}$ Geçmiş ve günümüz için önemli bir yere sahip olan din eğitimi kurumsal olarak ve eğitim programlarıyla ilgili birçok değişikliğe uğramıştır. Kimine göre geçmişte derin izler bırakan medrese eğitimleri zamanla değişime ve gelişime uğrayarak günümüz üniversitelerine yerini bırakmıştır. Din eğitimi alanı da bu değişimden nasibini almış ve günümüz ilahiyat fakültelerine kendini emanet etmiştir. Değiş̧en çağa ayak uydurmaya çalışan diğer alanlar gibi din eğitimi alanı da günümüz şartlarına binaen daha iyi hizmet etmek, toplumsal ihtiyaçları ve beklentileri karşılayabilmek için kendini geliştirmeye devam etmektedir. ${ }^{9}$ Ayrıca Hizmet içi ve diğer bağlamlarda din eğitimi ile ilgili topluma daha nitelikli personel ve din hizmeti ihtiyacının karşılanması için Diyanet İşleri Başkanlığı ve Milli Eğitim Bakanlığı tarafından anayasanın ilgili maddesi gereği kurumsal performans ve toplam kalitenin arttırılmasına yönelik çaba gösterilmektedir. ${ }^{10}$

Temel olarak makalemizde ele alacağımı konu "Erzincan İl Milli Eğitim Müdürlüğü ve bağlı okullarında görev yapan kurum/okul yöneticilerinin ilahiyat fakültesi mezunu DKAB öğretmenlerinin mesleki uygulamalarından memnuniyet düzeyleri nedir?" sorusu üzerinden ele alınacaktır. Bu konuda yapılan bir araştırmaya göre İlahiyat fakültelerinin kendi alanında gelişmiş ve kendini değişen eğitim programlarındaki uyum sağlayarak geliştirmeye çalışan kurumlar olduğu belirtilmiştir. Fakat bu eğitim programlarındaki değişimlerin yeterli olmadığı, uluslararası alanlarda rekabet edebilmek için toplumumuzun ihtiyaçlarını ve beklentilerini karşılayabilmek, eğitim sistemimizdeki tek tip öğretimin ortaya koymuş olduğu olumsuz sonuçları ortadan kaldırmak ve daha iyi bir eğitim sistemine yönelik stratejiler belirleyebilmek için değişim ve gelişimin zorunlu

\footnotetext{
${ }^{8}$ Korukçu, “ỉlahiyat Fakültesi Son Sınıf Öğrencilerinin Yaygın Din Eğitimine Bakışları”; Abdullah Özbek, "ìlahiyat fakültelerinde ilmî araştırma zihniyetinin geliştirilmesi." (Yükseköğretimde Din Bilimleri Öğretimi Sempozyumu, Samsun: Ondokuz Mayıs Ünv. İlahiyat Fakültesi Yayınları, 1988), 45-53.

${ }^{9}$ Ali Rıza Gül, “Yüksek Din Eğitimi Kurumlarında Değişim ve Yenilenmenin Gerekçeleri”, Eskişehir Osmangazi Üniversitesi İlahiyat Fakültesi Dergisi 3/5 (15 Aralık 2016), 7-38; Varış, "Üniversitenin Değişen Fonksiyonu ve Birkaç Sorun".

${ }^{10}$ İbrahim Turan, “Din Görevlilerinin Mesleki Yeterlilikleri”, Dinbilimleri Akademik Araştırma Dergisi 13/3 (01 Haziran 2013), 47-73.
} 
olduğu belirtilmiştir. Bu açıdan baktığımızda sadece eğitim alanında bireyleri geliştirmek değil diğer tüm alanlarda (hastaneler, hapishaneler vb.) faydalı din hizmetinin verilmesi tanitılması topluma dönük alanlarda kendini daha fazla geliştirmesi gerekmektedir. ${ }^{11} \mathrm{Bu}$ açıdan değerlendirildiğinde sadece din eğitimi konusunda öğrencilere salt bilgi aktarımından ziyade toplumla iyi ilişkiler geliştirerek onlara bu din hizmetlerini sunabilmelerini sağlamak adına adımlar atmak önemli hale gelmektedir.

Toplumumuzda bu kadar önemli bir yere sahip olan din hizmetlerinin bu alanda çalışan kişilerin eğitimleri ya da deneyimleri insanların beklentilerini karşılayabiliyor mu? Sorusuna cevap olarak; din hizmetlerinde çalışan ilahiyat mezunlarının sayısının gün geçtikçe arttığını ve mezunların imamlık, müezzinlik, Kur'an kursu öğreticiliği, vaizlik/vaizelik, din hizmetleri uzmanlı̆̆1, Din Kültürü öğretmenliği ve müftülük gibi görevler yaptıklarını, bu görevleri yerine getirirken okullarında aldıkları bilgi ve eğitimin öğrenciler için yeterli olmadığını belirtilmektedir. $\mathrm{Bu}$ alanda kendilerini yeterli görmeyen mezunların çalıştıkları kurumdaki beklentileri karşılayamadığı düşüncesinden dolayı mesleğinden istifa edenler olmuştur. Bu durumu önlemek için Diyanet İşleri Bakanlığı çalışanlarına alanlarıyla ilgili dersler vermekte ve çalışanlarının istihdamını arttırmaya çalışmaktadır. ${ }^{12}$

Yapılan başka bir araştırmaya göre ilahiyat fakültesi programından mezun olan DKAB öğretmenlerinin toplumun ihtiyaçlarını ve beklentilerini karşılayabildikleri, fakat topluma daha üst bir hizmet sunabilmek için ilahiyat programlarının ele alınarak daha iyi bir eğitim programından geçmesi gerektiğini belirtmiştir. İlahiyat fakülteleri alanında her ne kadar eksiklikler bulunsa da din eğitimi alanında vazgeçilmez bir öneme sahiptir. ${ }^{13}$

İlahiyat fakültesi mezunlarını istihdam eden Milli Eğitimi Bakanlığı, Diyanet İşleri Başkanlığı gibi kurumların, üniversiteden mezun olan ve çalışma hayatına başlayan kişilerden bazı beklentileri bulunmaktadır. Bu beklentiler, öncelikle üniversite yıllarında eğitim alan öğrencilerin iletişim ve sosyalleşme konusunda başarılı olmaları, alanlarıyla ilgili yeteneklerini geliştirmeleri, geçmiş bilgileri öğrenip yeni bilgileri içselleştirerek uygulayabilmeleri ve mesleki alanda kendini geliştirmiş olmalarıdır. Yukarıda belirtilen bazı araştırmalarda görülmektedir ki üniversitelerinden mezun olan DKAB öğretmenlerinin bir kısmı bu beklentileri karşılayabilirken bir kısmı da yetersiz kalabilmektedir.

\footnotetext{
${ }^{11}$ Gül, "Yüksek Din Eğitimi Kurumlarında Değişim ve Yenilenmenin Gerekçeleri”.

${ }^{12}$ Korkmaz, "İlahiyat Fakültelerinin Yaygın Din Eğitimi Yeterlikleri”.

${ }^{13}$ Korukçu, “ílahiyat Fakültesi Son Sınıf Öğrencilerinin Yaygın Din Eğitimine Bakışları”.
} 
Bu çalışmada, Millî Eğitim Bakanlığı'nda görev yapan DKAB öğretmenlerinden mesleki yeterlilik algıları, alan bilgisi, beceri ve uygulama yeterlilikleri bakımından kurum yöneticilerinin memnuniyeti ve beklentilerini ne düzeyde karşıladığı incelenmiştir.

\section{Yöntem}

\subsection{Amaç ve Önem}

Çalışmamızın amacı, Erzincan İl Milli Eğitim Müdürlüğü Yöneticileri ile Erzincan İl Milli Eğitim Müdürlüğüne bağlı olarak görev yapan Temel Eğitim ve Orta Öğretim Kurum yöneticilerinin kurumlarında görev yapan olan Din Kültürü Ahlak Bilgisi öğretmenlerinden memnuniyet düzeylerini ve beklentilerini karşılayıp karşılamadığına dair düşüncelerini tespit etmektir. Ayrıca bu tespitler üzerinden özelden genele doğru yorum yaparak anlamaya ve böylece Türkiye'deki bütün MEB`e bağlı kurum yöneticilerinin ilahiyat fakültesi mezunlarından beklentilerine ışık tutmaya çalışmaktır.

\subsection{Evren ve Örneklem}

2019-2020 eğitim-öğretim yıll, Erzincan ilinde İlahiyat fakültesi mezunu \%12,3’ü (9 kişi) Erzincan İl Milli Eğitim Müdürlüğünde çalışan şube müdürü, \%41,1’i (34 kişi) Temel Eğitim (Ortaokul kısmı), \%46,6’sı (30 kişi) Orta Öğretim kurumlarında çalışan toplam 73 erkek kurum yöneticisinden elde edilmiştir. Anketlerin dağıtıldığı toplantıya kadın yöneticilerden hiç katılım olmaması sebebiyle görüşlerine başvurulamamıştır. Katılımcı sayısı, Erzincan ilinde söz konusu dönemde eğitim-öğretim yılında çalışan toplam kurum yöneticilerinin sayısı dikkate alındığında (9 şube müdürü, 59 ortaokul müdürü/müdür yardımcısı, 49 lise müdürü/müdür yardımcısı olmak üzere toplam 117 kişi), evreni temsil ettiği söylenebilir.

\subsection{Uygulama}

Araştırmada tekil tarama modeli kullanılmıştır. Bu model, "değişkenlerin, tek tek ya da miktar olarak oluşumların belirlenmesi amacı ile yapılan araştırma modeli" şeklinde tanımlanabilir. Modelin amacı, ilgilenilen birey, grup, kurum vb. duruma ait değişkenlerin geçmiş veya şimdiki zamanda sınırlı bir şekilde ya da zamana bağlı olarak gelişimsel şekilde ayrı ayrı betimlenmesidir. ${ }^{14}$

Araştırma, Erzincan İl Milli Eğitim Müdürlüğü ve bağlı okullarında görev yapan toplam 73 gönüllü yöneticinin katılımıyla yapılan bir çalışmadır. Katılımcılar, araştırmacı tarafından bu çalışma için hazırlanan 22 soruluk dış paydaşım değerlendirme anketi ile demografik özelliklerini ortaya koymak amacıyla 6 soruluk kişisel bilgi formunu cevaplamışlardır. Dış paydaş anketleri Erzincan Binali yıldırım Üniversitesi İnsan Araştırmaları Etik Kurulunun 29/05/2020 tarih ve 05/04

${ }^{14}$ Niyazi Karasar, Bilimsel Araştırma Yöntemleri (Ankara: Nobel Yayın Dağıtım, 2012). 
protokol numaralı kararı doğrultusunda 1-7/06/2020 tarihleri arasında sosyal mesafe ve hijyen kurallarına uygun şekilde Erzincan İl Milli Eğitim Müdürlüğünün yöneticileri ile Halk Eğitim Merkezi Müdürlüğü toplantı salonda düzenlediği yıl sonu toplantılarına katılan yöneticiler arasında uygulanmıştır. Araştırmanın analiz kısmında, anket formundan elde edilen bulguların frekans ve yüzde dağılımları SPSS 20.0 (Statistical Package for Social Science) istatistik paket programıla çözümlenmiştir. Elde edilen veriler tablolar haline getirilerek yorumlanmıştır.

\subsection{Araştırmanın Sınırlılıkları}

Bu araştırma, 2019-2020 eğitim-öğretim yılı, Erzincan il merkezinde görev yapan il milli eğitim şube müdürü, temel eğitim (ortaokul kısmı) ve orta öğretim kurumlarında görev yapan yöneticilerine uygulanan dış paydaş program değerlendirme anket sonuçları ile sınırlıdır.

\subsection{Araştırmanın Hipotezleri}

Araştırmada, ilgili literatür araştırması ve yapılan gözlemlere bağlı olarak aşağıdaki hipotezlerin doğruluğu sınanmıştır:

Erzincan il milli eğitim müdürlüğü ve bağlı okullarında çalışan kurum yöneticilerine göre;

1- İlahiyat fakültesinden mezun DKAB öğretmenlerinin aldıkları eğitim kurumların beklentileri karşılayabilmektedir.

2- İlahiyat fakülteleri tarafından verilen mezun sayısı MEB`e bağlı kurum ve okulların ihtiyacını karşılamaktadır.

3- İlahiyat fakültesinden mezun olan DKAB öğretmenleri mesleki bilgi bakımından yeterli görülmektedir.

4- İlahiyat fakültesi mezunu DKAB öğretmenleri, iletişim becerileri ve mesleki yeterlilikleri bakımından beklentileri karşılayabilmektedir.

5- İlahiyat fakültesi mezunu DKAB öğretmenleri, çalıştıkları kurumlara alanlarıyla ilgili katkı sağlayabilmektedir.

\section{Bulguların Analizi ve Yorumlanmasi}

Araştırmanın bu kısmında, araştırmanın amaçları doğrultusunda elde edilen verilerin analiz sonuçlarının yorumlarına yer verilmiştir. Katılımcıların cinsiyet, yaş, medeni hali, bölümü, mesleki kıdemi ve çalışma türüne göre frekans ve yüzde dağılımları ve katılımcıların dış paydaş anketine verdikleri cevapların frekans ve yüzde dağılımları verilmiştir. 
Göksu-Güven, Expectations of Institutional Administrators Working in the Ministry of National Education from the Graduates

\subsection{Sosyo-Demografik Değişkenler Yorumu}

Tablo 1.1. Katılımcıların Cinsiyet Durumu ve Medeni Hali Açısından Dağılımı

\begin{tabular}{llrr}
\hline Değişkenle & & Sayı & Yüzde \\
Cinsiyet & Erkek & 73 & 100,0 \\
Toplam & & 73 & 100,0 \\
& Evli & 64 & 87,6 \\
Medeni Hali & Bekar & 7 & 9,5 \\
Toplam & & 73 & $\mathbf{1 0 0 , 0}$ \\
\hline
\end{tabular}

Tablo 1.1.'de görüldüğü gibi katılımcıların, \%100,0 ’ü (73 kişi) erkeklerden oluşmaktadır. Anketin dağıtıldığı toplantıya hiçbir kadın yönetici katılmadığı için görüşlerine başvuramamıştır. (Ill Milli Eğitim Müdürlüğü yöneticilerinden edinilen bilgiye göre kurumlarda görev yapan kadın yönetici sayısı oldukça azdır.) Katılımcıların \%84,7'si (64 kişi) evli, 9,5’i (7 kişi) bekar kişilerden oluşmaktadır. Ayrıca katılımcıların \%2,7`si (2 kişi) "medeni hali” sorusuna cevap vermemiştir. Yöneticilerin cinsiyet özelliklerine göre erkek egemen ve çoğunlukla aile babası kişilerden oluştuğu görülmektedir.

Tablo 1.2. Katılımcıların Yaş Aralık Durumları Açısından Dağılımı

\begin{tabular}{llrr}
\hline Değişkenler & & Sayı & Yüzde \\
& $20-30$ & 7 & 9,6 \\
Yaş & $31-40$ yaş & 28 & 38,3 \\
& $41-50$ yaş & 33 & 45,2 \\
& 51 ve Üzeri & 5 & 6,9 \\
Toplam & & 73 & 100,0 \\
\hline
\end{tabular}

Tablo 1.2.'de görüldüğü gibi katılımcıların çoğunluğu 31-50 yaş aralığı kişilerden oluşmaktadır. Bu duruma göre Erzincan İl Milli Eğitim Müdürlüğü yöneticilerinin orta yaş grubu bir profil sergiledikleri görülmektedir.

Tablo 1.3. Katılımcıların Okuduğu Bölüm Durumları Açısından Dağılımı

\begin{tabular}{llrr}
\hline Değişkenler & & Sayı & Yüzde \\
& İlahiyat Fakültesi & 9 & 12,3 \\
Bölümü & Eğitim Fakültesi & 39 & 53,4 \\
& Mesleki Teknik Eğitim Fakültesi & 13 & 17,8 \\
& Güzel Sanatlar Fakültesi & 2 & 2,7 \\
& Diğer & 4 & 5,5 \\
Toplam & & $\mathbf{6 7}$ & $\mathbf{9 2 , 0}$ \\
\hline
\end{tabular}


Tablo 1.3.'de görüldüğü gibi katılımcıların, \%12,3’ü (9 kişi) İlahiyat Fakültesi, \%53,4’ü (39 kişi) Eğitim Fakültesi, \%17,8’i (13 kişi) Mesleki Teknik Eğitim Fakültesi, \%2,7’si (2 kişi) Güzel Sanatlar Fakültesi iken, \%5,5' i (4 kişi) diğer bölümlerden oluşmaktadır. Ayrıca katılımcıların \%8’i (6 kişi) bu soruya cevap vermemiştir. Yöneticilerin ağırlıklı olarak eğitim fakültesi mezunlarından oluştuğu görülmektedir.

Tablo 1.4. Katılımcıların Mesleki Kıdem Durumu Açısından Dağılımı

\begin{tabular}{llrr}
\hline Değişkenler & & Sayı & Yüzde \\
& 0-10 yll arası & 8 & 10.9 \\
Mesleki Kıdemi & 11-20 yll arası & 31 & 42,4 \\
& 21-30 yıl aras1 & 28 & 38,4 \\
& 31 ve üzeri & 6 & 8,3 \\
Toplam & & 73 & $\mathbf{1 0 0 , 0}$ \\
\hline
\end{tabular}

Tablo 1.4.'de görüldüğü gibi katılımcıların, \%10,9'u (8 kişi) 0 ile 10 yıl arası, \%42,4’ü (31 kişi) 11 ile 20 yıl arası, \%38,4'ü (28 kişi) 21 ile 30 yıl arası, \%8,3’ü (6 kişi) 31 yıl ve üzeri mesleki tecrübeleri bulunmaktadır. Yöneticilerin büyük çoğunluğunun 11-30 yılları arası mesleki deneyime sahip oldukları görülmektedir.

Tablo 1.5. Katılımcıların Görev Yaptıkları Kurum Açısından Dağılımı

\begin{tabular}{lllrr}
\hline Değişkenler & & & Sayı & Yüzde \\
Okul/Kurum & & İmam Hatip Lisesi & 7 & 9,6 \\
Türü & & Anadolu Lisesi & 11 & 15 \\
& Lise & Meslek Lisesi & 12 & 16,4 \\
& & Proje Okulu & 4 & 5,4 \\
& Ortaokul & İmam Hatip Ortaokulu & 6 & 8,2 \\
& & Ortaokul & 18 & 24,6 \\
& İl Milli & & & \\
& Eğitim & Şube Müdürü & 9 & 12,3 \\
Toplam & Müdürlüğü & & 67 & \\
\hline
\end{tabular}

Tablo 1.5.'de görüldüğü gibi katılımcıların, \%12,3'ü (9 kişi) İmam Hatip Lisesi, \%16,4'ü (12 kişi) Anadolu Lisesi, \%17,8’i (13 kişi) Meslek Lisesi, \%6,8'i (5 kişi) Proje Okulu gruplarını oluştururken \%8,2'si (6 kişi) İmam Hatip Ortaokulu, \%24,6’sı normal ortaokul (18 kişi) ve 12,3 ü (9 kişi) şube müdürlerinden oluşmaktadır. Ayrıca \%8'i (6 kişi) cevap vermemiştir. 
Göksu-Güven, Expectations of Institutional Administrators Working in the Ministry of National Education from the Graduates

Tablo 1.6. Çalışma Grubunda Yer Alan Yöneticilerin Unvanlarına Göre Dağılımı.

\begin{tabular}{llrr}
\hline Değişkenler & & Sayı & Yüzde \\
& İl Milli Eğitim Şube Müdürü & 09 & 12,3 \\
Çalışma Grubu & Ortaokul Okul Yöneticileri & 30 & 41,1 \\
& Lise Okul Yöneticileri & 34 & 46,6 \\
Toplam & & $\mathbf{7 3}$ & $\mathbf{1 0 0 , 0}$ \\
\hline
\end{tabular}

Tablo 1.6.'da görüldüğü gibi katılımcıların, \%12,3’ü (9 kişi) İl Milli Eğitim Şube Müdürü, \%41,1'i (30 kişi) Ortaokul iken, \%46,6's1 (34 kişi) Lisede görev yapan yöneticilerden kişilerden oluşmaktadır.

\subsection{Diş Paydaş Değerlendirme Anketinin Yorumu}

Tablo 2.1. Mezun Sayısı Dağılımı

\begin{tabular}{|c|c|c|c|}
\hline \multirow{7}{*}{ 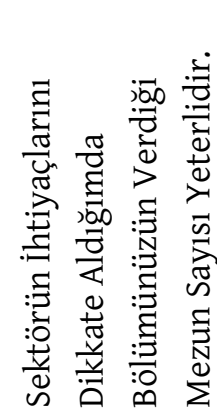 } & & Say1 & Yüzde \\
\hline & Kesinlikle Katılmıyorum & 8 & 11,0 \\
\hline & Katılmiyorum & 11 & 15,1 \\
\hline & Kararsızım & 7 & 9,6 \\
\hline & Katıllyorum & 24 & 32,9 \\
\hline & Kesinlikle Katıliyorum & 23 & 31,5 \\
\hline & Toplam & 73 & 100,0 \\
\hline
\end{tabular}

Tablo 2.1.'de görüldüğü gibi araştırmaya katılan olan örneklem grubunun, "Sektörün ihtiyaçlarını dikkate aldığımda bölümünüzün verdiği mezun sayısı yeterlidir." sorusuna; \%11,0'ı (8 kişi) “Kesinlikle Katılmıorum”, \%15,1'i (11 kişi) "Katılmıorum”, \%9,6’s1 (7 kişi) "Kararsızım”, \%32,9'u (24 kişi) “Katılıyorum”, \%31,5'i (23 kişi) “Kesinlikle Katılıyorum” cevabını vermiştir. Elde edilen verilere göre katılımcılar, mevcut mezun DKAB öğretmenleri sayısının sektörün ihtiyacını karşıladığını düşünmektedir.

Tablo 2.2. Mesleki Bilgi Düzeyi Dağılımı

\begin{tabular}{|c|c|c|c|}
\hline \multirow{7}{*}{ 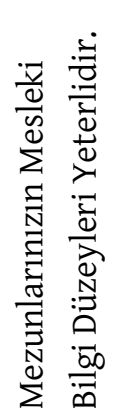 } & & Say1 & Yüzde \\
\hline & Kesinlikle Katılmiyorum & 3 & 4,1 \\
\hline & Katılmiyorum & 17 & 23,3 \\
\hline & Kararsızım & 16 & 21,9 \\
\hline & Kat1lyyorum & 35 & 47,9 \\
\hline & Kesinlikle Katılıyorum & 2 & 2,7 \\
\hline & Toplam & 73 & 100,0 \\
\hline
\end{tabular}


Tablo 2.2.'de görüldüğü gibi araştırmaya katılan olan örneklem grubunun, "Mezunlarımızın mesleki bilgi düzeyleri yeterlidir.” sorusuna; \%4,1'i (3 kişi) "Kesinlikle Katılmıorum”, \%23,3’ü (17 kişi) “Katılmıyorum”, \%21,9'u (16 kişi) “Kararsızım”, \%47,9'u (35 kişi) “Katılıyorum”, \%2,7'1 (2 kişi) "Kesinlikle Katılıyorum" cevabını vermiştir. Elde edilen verilere göre katılımcılar, İlahiyat Fakültesi bölümünden mezun olan $\mathrm{DKAB}$ öğretmenlerinin mesleki bilgi düzeylerinin yeterli olduğunu belirtmişlerdir.

Tablo 2.3. Mesleki Pratik Beceriler Dağılımı

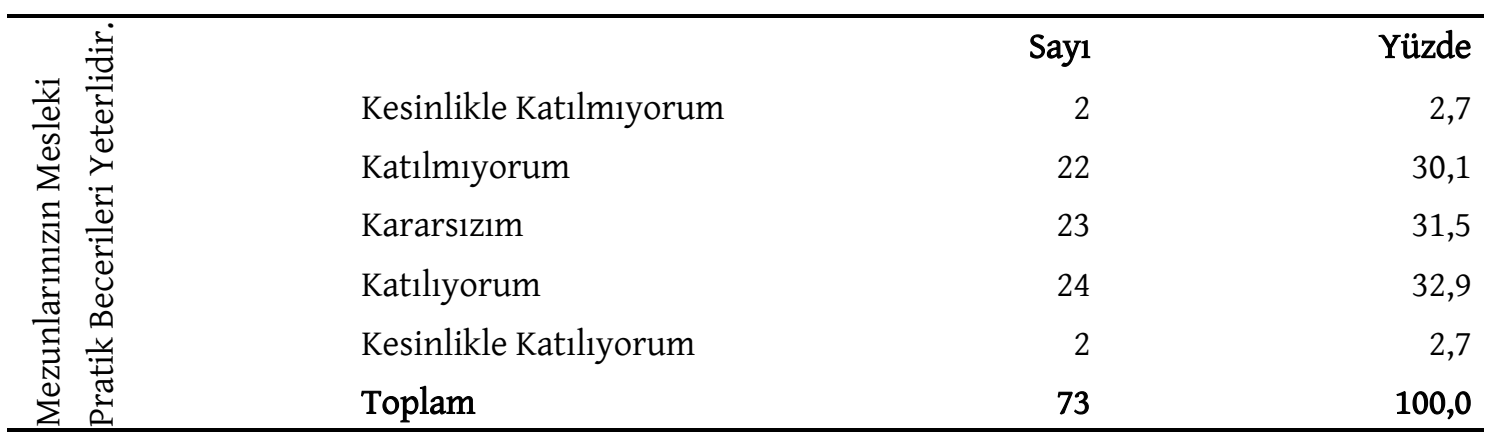

Tablo 2.3.'de görüldüğü gibi araştırmaya katılan olan örneklem grubunun, "Mezunlarımızın mesleki pratik becerileri yeterlidir.” sorusuna; \%2,7'si (2 kişi) “Kesinlikle Katılmıyorum”, \%30,1'i (22 kişi) “Katılmıyorum”, \%31,5’i (23 kişi) “Kararsızım”, \%32,9’u (24 kişi) “Katılıyorum”, \%2,7’si (2 kişi) "Kesinlikle Katılıyorum" cevabını vermiştir. Elde edilen verilere göre katılımcıların bir kısmı İlahiyat Fakültesi bölümünden mezun olan DKAB öğretmenlerinin mesleki pratik becerilerini yeterli bulurken bu görüşe karşı pratik becerilerin yetersiz olduğu görüşünü düşünen ve bu konu hakkında kararsız olan kişilerde bulunmaktadır.

Tablo 2.4. Yabancı Dil Becerileri Dağılımı

\begin{tabular}{|c|c|c|c|}
\hline \multirow{7}{*}{ 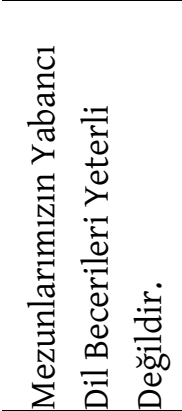 } & & Say 1 & Yüzde \\
\hline & Kesinlikle Katılmıyorum & 9 & 12,3 \\
\hline & Katılmiyorum & 24 & 32,9 \\
\hline & Kararsızım & 15 & 20,5 \\
\hline & Katıliyorum & 22 & 30,1 \\
\hline & Kesinlikle Katıliyorum & 3 & 4,1 \\
\hline & Toplam & 73 & 100,0 \\
\hline
\end{tabular}

Tablo 2.4.'de görüldüğü gibi araştırmaya katılan olan örneklem grubunun, "Mezunlarımızın yabancı dil becerileri yeterli değildir." sorusuna; \%12,3’ü (9 kişi) “Kesinlikle Katılmıyorum”, \%32,9’u (24 kişi) “Katılmıyorum”, \%20,5’i (15 kişi) “Kararsızım”, \%30,1’u (22 kişi) “Katıllyorum”, \%4,1’i (3 kişi) "Kesinlikle Katılıyorum" cevabını vermiştir. Elde edilen verilere göre, İlahiyat Fakültesi 
Göksu-Güven, Expectations of Institutional Administrators Working in the Ministry of National Education from the Graduates

bölümünden mezun olan DKAB öğretmenlerinin yabancı dil becerilerinin yöneticiler tarafından yeterli bulunduğu görülmektedir.

Tablo 2.5. İletişim Becerileri Dağılımı

\begin{tabular}{|c|c|c|c|}
\hline \multirow{7}{*}{ 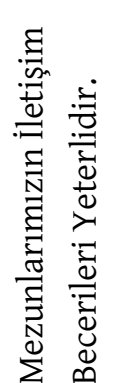 } & & Say & Yüzde \\
\hline & Kesinlikle Katılmiyorum & 3 & 4,1 \\
\hline & Katılmiyorum & 15 & 20,5 \\
\hline & Kararsızım & 11 & 15,1 \\
\hline & Katıliyorum & 39 & 53,4 \\
\hline & Kesinlikle Katıliyorum & 4 & 5,5 \\
\hline & Toplam & 73 & 100,0 \\
\hline
\end{tabular}

Tablo 2.5.'de görüldüğğu gibi araştırmaya katılan olan örneklem grubunun, "Mezunlarımızın iletişim becerileri yeterlidir." sorusuna; \%4,1'i (3 kişi) "Kesinlikle Katılmıyorum", \%20,5’i (15 kişi) "Katılmıyorum", \%15,1'i (11 kişi) “Kararsızım”, \%53,4’ü (39 kişi) “Katılıyorum”, \%5,5’i (4 kişi) "Kesinlikle Katılıyorum" cevabını vermiştir. Ayrıca katılımcıların \%1,4’ü (1 kişi) bu soruya cevap vermemiştir. Elde edilen verilere göre, İlahiyat Fakültesi bölümünden mezun olan DKAB öğretmenlerinin iletişim becerilerinin yeterli olduğu bulunmuştur.

Tablo 2.6. Teknoloji Kullanım Becerileri Dağılımı

\begin{tabular}{|c|c|c|c|}
\hline \multirow{7}{*}{ 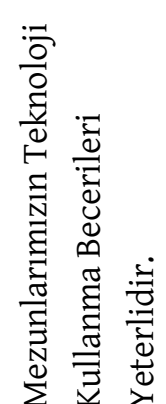 } & & Sayı & Yüzde \\
\hline & Kesinlikle Katılmiyorum & 2 & 2,7 \\
\hline & Katılmıyorum & 9 & 12,3 \\
\hline & Kararsızım & 18 & 24,7 \\
\hline & Katıliyorum & 34 & 46,6 \\
\hline & Kesinlikle Katılıyorum & 10 & 13,7 \\
\hline & Toplam & 73 & 100,0 \\
\hline
\end{tabular}

Tablo 2.6.'da görüldüğg̈u gibi araştırmaya katılan olan örneklem grubunun, "Mezunlarımızın teknoloji kullanma becerileri yeterlidir" sorusuna; \%2,7'si (2 kişi) "Kesinlikle Katılmıyorum", \%12,3’ü (9 kişi) “Katılmıyorum”, \%24,7’si (18 kişi) “Kararsızım”, \% 46,6’sı (34 kişi) “Katılıyorum”, \%13,7'si (10 kişi) "Kesinlikle Katılıyorum” cevabını vermiştir. Elde edilen verilere göre, İlahiyat Fakültesi bölümünden mezun olan DKAB öğretmenlerinin teknoloji kullanma becerilerinin yeterli olduğu görülmektedir. 
Tablo 2.7. Kurum/Okula Katkı Dağılımı

\begin{tabular}{|c|c|c|c|}
\hline \multirow{7}{*}{ 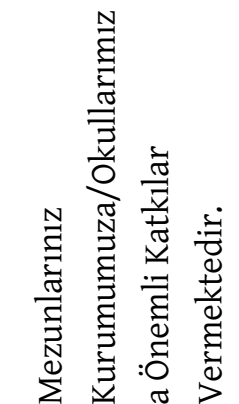 } & & Say1 & Yüzde \\
\hline & Kesinlikle Katılmıyorum & 5 & 6,8 \\
\hline & Katılmiyorum & 8 & 11,0 \\
\hline & Kararsızım & 19 & 26,0 \\
\hline & Katıliyorum & 36 & 49,3 \\
\hline & Kesinlikle Katılıyorum & 4 & 5,5 \\
\hline & Toplam & 73 & 100,0 \\
\hline
\end{tabular}

Tablo 2.7.'de görüldüğü gibi araştırmaya katılan olan örneklem grubunun, "Mezunlarınız kurum/okullarımıza önemli katkılar vermektedir." sorusuna; \%6,8'i (5 kişi) "Kesinlikle Katılmıyorum”, \%11,0'ı (8 kişi) “Katılmıyorum”, \%26,0'1 (19 kişi) “Kararsızım”, \%46,3’ü (36 kişi) "Katılıyorum", \%5,5’i (4 kişi) "Kesinlikle Katılıyorum" cevabını vermiştir. Ayrıca katılımcıların \%1,4'ü (1 kişi) bu soruya cevap vermemiştir. Elde edilen verilere göre, İlahiyat Fakültesi bölümünden mezun olan DKAB öğretmenlerinin çalıştığı işletmelere önemli katkıları olduğu görülmektedir.

Tablo 2.8. Yenilikçi Öneri Getirme Düzeyi Dağılımı

\begin{tabular}{|c|c|c|c|}
\hline \multirow{7}{*}{ 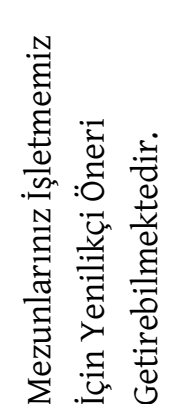 } & & Say1 & Yüzde \\
\hline & Kesinlikle Katılmiyorum & 6 & 8,2 \\
\hline & Katılmiyorum & 10 & 13,7 \\
\hline & Kararsızım & 27 & 37,0 \\
\hline & Katıliyorum & 28 & 38,4 \\
\hline & Kesinlikle Kat1lıyorum & 2 & 2,7 \\
\hline & Toplam & 73 & 100,0 \\
\hline
\end{tabular}

Tablo 2.8.'de görüldüğü gibi araştırmaya katılan olan örneklem grubunun, "Mezunlarınız işletmemiz için yenilikçi öneri getirebilmektedir." sorusuna; \%8,2'si (6 kişi) "Kesinlikle Katılmıyorum”, \%13,7'ü (10 kişi) “Katılmıyorum”, \%37,0’1 (27 kişi) “Kararsızım”, \%38,4’u (28 kişi) "Katılıyorum”, \%2,7'si (2 kişi) "Kesinlikle Katılıyorum” cevabını vermiştir. Elde edilen verilere göre, ilahiyat fakültesi bölümünden mezun olan DKAB öğretmenlerinin işletme için yenilikçi öneriler getirdikleri görülmektedir. 
Tablo 2.9. Örgüt Kültürüne Uyum Sağlama Düzeyi Dağılımı

\begin{tabular}{|c|c|c|c|}
\hline & Say1 & Yüzde \\
\hline \multirow{6}{*}{ 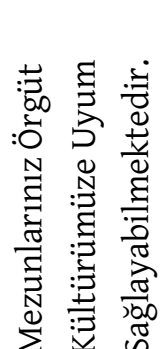 } & Kesinlikle Katılmıyorum & 3 & 4,1 \\
\hline & Katılmiyorum & 9 & 12,3 \\
\hline & Kararsızım & 18 & 24,7 \\
\hline & Katılıyorum & 38 & 52,1 \\
\hline & Kesinlikle Katılıyorum & 5 & 6,8 \\
\hline & Toplam & 73 & 100,0 \\
\hline
\end{tabular}

Tablo 9.'da görüldüğü gibi araştırmaya katılan olan örneklem grubunun, "Mezunlarınız örgüt kültürümüze uyum sayılabilmektedir." sorusuna; \%4,1’i (3 kişi) “Kesinlikle Katılmıyorum”, \%12,3’ü (9 kişi) “Katılmıyorum”, \%24,7’si (18 kişi) “Kararsızım”, \%52,1’i (38 kişi) “Katıllyorum”, \%6,8’i (5 kişi) "Kesinlikle Katılıyorum" cevabını vermiştir. Elde edilen verilere göre, İlahiyat Fakültesi bölümünden mezun olan DKAB öğretmenlerinin kurum kültürüne uyum sağlayabildikleri görülmektedir.

Tablo 2.10. Görev Tanımından Fazlasını Yapma İsteklerini Gösterir Dağılım

\begin{tabular}{|c|c|c|c|}
\hline & & Sayı & Yüzde \\
\hline \multirow{6}{*}{ 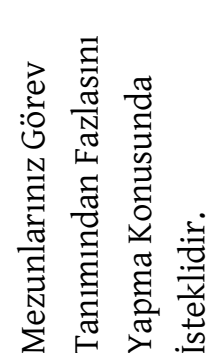 } & Kesinlikle Katılmiyorum & 1 & 1,4 \\
\hline & Katılmiyorum & 18 & 24,7 \\
\hline & Kararsızım & 22 & 30,1 \\
\hline & Katıliyorum & 27 & 37,0 \\
\hline & Kesinlikle Katıliyorum & 5 & 6,8 \\
\hline & Toplam & 73 & 100,0 \\
\hline
\end{tabular}

Tablo 2.10.'da görüldüğü gibi araştırmaya katılan olan örneklem grubunun, "Mezunlarınız görev tanımından fazlasını yapma konusunda isteklidir." sorusuna; \%1,4’ü (1 kişi) "Kesinlikle Katılmıyorum”, \%24,7'si (18 kişi) “Katılmıyorum”, \%30,1'1 (22 kişi) “Kararsızım”, \%37,0’1 (27 kişi) "Katılıyorum", \%6,8'i (5 kişi) "Kesinlikle Katılıyorum" cevabını vermiştir. Elde edilen verilere göre, İlahiyat Fakültesi bölümünden mezun olan DKAB öğretmenlerinin görev tanımından fazlasını yapma konusunda istekli oldukları görülmektedir. 
Tablo 2.11. Diğer Çalışanlara Örnek Olma Düzeyini Gösterir Dağılım

\begin{tabular}{|c|c|c|c|}
\hline \multirow{7}{*}{ 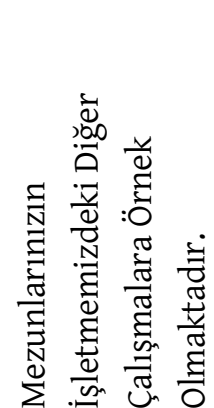 } & & Sayı & Yüzde \\
\hline & Kesinlikle Katılmiyorum & 1 & 1,4 \\
\hline & Katılmiyorum & 15 & 20,5 \\
\hline & Kararsızım & 20 & 27,4 \\
\hline & Katilıyorum & 31 & 42,5 \\
\hline & Kesinlikle Katılıyorum & 6 & 8,2 \\
\hline & Toplam & 73 & 100,0 \\
\hline
\end{tabular}

Tablo 2.11.'de görüldüğü gibi araştırmaya katılan olan örneklem grubunun, "Mezunlarınızın işletmemizdeki diğer çalışmalara örnek olmaktadır." sorusuna; \%1,4’ü (1 kişi) “Kesinlikle Katılmıyorum”, \%20,5'i (15 kişi) “Katılmıyorum”, \%27,4'1 (20 kişi) “Kararsızım”, \%42,5'i (31 kişi) “Katılıyorum”, \%8,2'si (6 kişi) “Kesinlikle Katılıyorum” cevabını vermiştir. Elde edilen verilere göre, İlahiyat Fakültesi bölümünden mezun olan DKAB öğretmenlerinin çalıştıkları işletmelerdeki diğer çalışmalara örnek oldukları görülmektedir.

Tablo 2.12. Diğer Çalışanları Eğitebilme Düzeyini Gösterir Dağılım

\begin{tabular}{|c|c|c|c|}
\hline \multirow{7}{*}{ 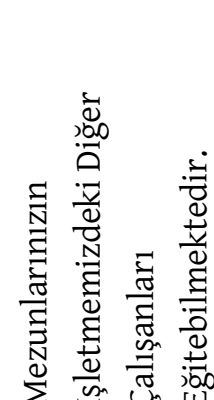 } & & Say1 & Yüzde \\
\hline & Kesinlikle Katılmiyorum & 2 & 2,7 \\
\hline & Katılmiyorum & 25 & 34,2 \\
\hline & Kararsızım & 27 & 37,0 \\
\hline & Kat1lyyorum & 17 & 23,3 \\
\hline & Kesinlikle Katılıyorum & 1 & 1,4 \\
\hline & Toplam & 73 & 100,0 \\
\hline
\end{tabular}

Tablo 2.12.'de görüldüğg̈ gibi araştırmaya katılan olan örneklem grubunun, "Mezunlarınızın işletmemizdeki diğer çalışanları eğitebilmektedir" sorusuna; \%2,7’si (2 kişi) "Kesinlikle Katılmıyorum”, \%34,2'si (25 kişi) “Katılmıyorum”, \%37,0’1 (27 kişi) “Kararsızım”, \%23,3’ü (17 kişi) "Katılıyorum”, \%1,4'si (1 kişi) "Kesinlikle Katılıyorum" cevabını vermiştir. Ayrıca katılımcıların \%1,4'ü (1 kişi) bu soruya cevap vermemiştir. Elde edilen verilere göre, İlahiyat Fakültesi bölümünden mezun olan DKAB öğretmenlerinin çalıştıkları işletmelerdeki diğer çalışanları eğitebildikleri konusunda kararsız oldukları görülmektedir. 
Tablo 2.13. Takım Çalışmasına Katılım Düzeyini Gösterir Dağılım

\begin{tabular}{|c|c|c|c|}
\hline \multirow{7}{*}{ 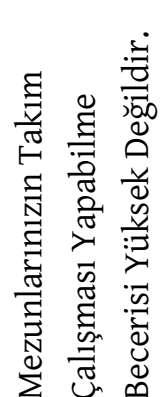 } & & Say1 & Yüzde \\
\hline & Kesinlikle Katılmıyorum & 3 & 4,1 \\
\hline & Katılmiyorum & 25 & 34,2 \\
\hline & Kararsızım & 12 & 16,4 \\
\hline & Katıliyorum & 31 & 42,5 \\
\hline & Kesinlikle Katılıyorum & 2 & 2,7 \\
\hline & Toplam & 73 & 100,0 \\
\hline
\end{tabular}

Tablo 2.13.'de görüldüğü gibi araştırmaya katılan olan örneklem grubunun, "Mezunlarınızın takım çalışması yapabilme becerisi yüksek değildir." sorusuna; \%4,1'i (3 kişi) “Kesinlikle Katılmıyorum", \%34,2'si (25 kişi) "Katılmıyorum”, \%16,4'ü (12 kişi) "Kararsızım”, \%42,5’i (31 kişi) "Katıllyorum”, \%2,7'si (2 kişi) “Kesinlikle Katılıyorum” cevabını vermiştir. Elde edilen verilere göre, İlahiyat Fakültesi bölümünden mezun olan DKAB öğretmenlerinin takım çalışması yapabilme becerilerinin yüksek olmadığı görülmektedir.

Tablo 2.14. Eğitim Programları Düzenlenmesi Talep Dağılımı

\begin{tabular}{|c|c|c|c|}
\hline$\underline{\vec{E}}$ & & Sayı & Yüzde \\
\hline 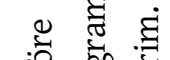 & Kesinlikle Katılmıyorum & 3 & 4,1 \\
\hline 莞 & Katılmiyorum & 6 & 8,2 \\
\hline 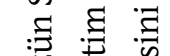 & Kararsızım & 4 & 5,5 \\
\hline : & Katıliyorum & 33 & 45,2 \\
\hline : & Kesinlikle Katıliyorum & 27 & 37,0 \\
\hline$\overline{: 00}: \overline{0}$ & Toplam & 73 & 100,0 \\
\hline
\end{tabular}

Tablo 2.14.'de görüldüğü gibi araştırmaya katılan olan örneklem grubunun, "Bölümünüzün sektöre yönelik eğitim programları düzenlemesini isterim" sorusuna; \%4,1'i (3 kişi) "Kesinlikle Katılmıyorum”, \%8,2'si (6 kişi) “Katılmıyorum”, \%5,5’i (4 kişi) “Kararsızım”, \%45,2'si (33 kişi) "Katılıyorum”, \%37,0'ı (27 kişi) "Kesinlikle Katılıyorum" cevabını vermiştir. Elde edilen verilere göre, İlahiyat Fakültesi bölümünden mezun olan kişiler sektöre yönelik eğitim programları düzenlemesini istedikleri görülmektedir. 
Tablo 2.15. Araştırma Sonuçlarının Sektörle Paylaşım Talebini Gösterir Dağılım

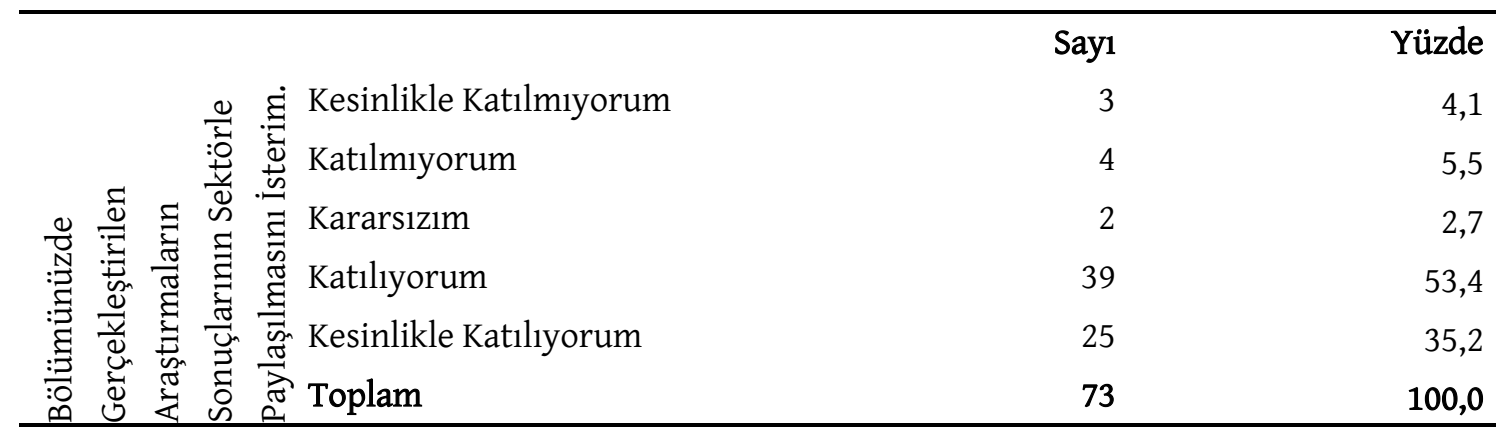

Tablo 2.15.'de görüldüğü gibi araştırmaya katılan olan örneklem grubunun, "Bölümünüzde gerçekleştirilen araştırmaların sonuçlarının sektörle paylaşılmasını isterim." sorusuna; \%4,1’i (3 kişi) “Kesinlikle Katılmıyorum”, \%5,5’i (4 kişi) “Katılmıyorum”, \%2,7’si (2 kişi) “Kararsızım”, \%53,4’ü (39 kişi) “Katılıyorum”, \%35,2'si (25 kişi) “Kesinlikle Katılıyorum” cevabını vermiştir. Elde edilen verilere göre, İlahiyat Fakültesi bünyesinde yapılan MEB ile ilgili araştırmaların sonuçlarının kurum çalışanları olarak kendileri ile paylaşılmasını istediklerini belirtmişlerdir.

Tablo 2.16. Araştırma Altyapısını Sektörle Paylaşılması İsteğini Gösterir Dağılım

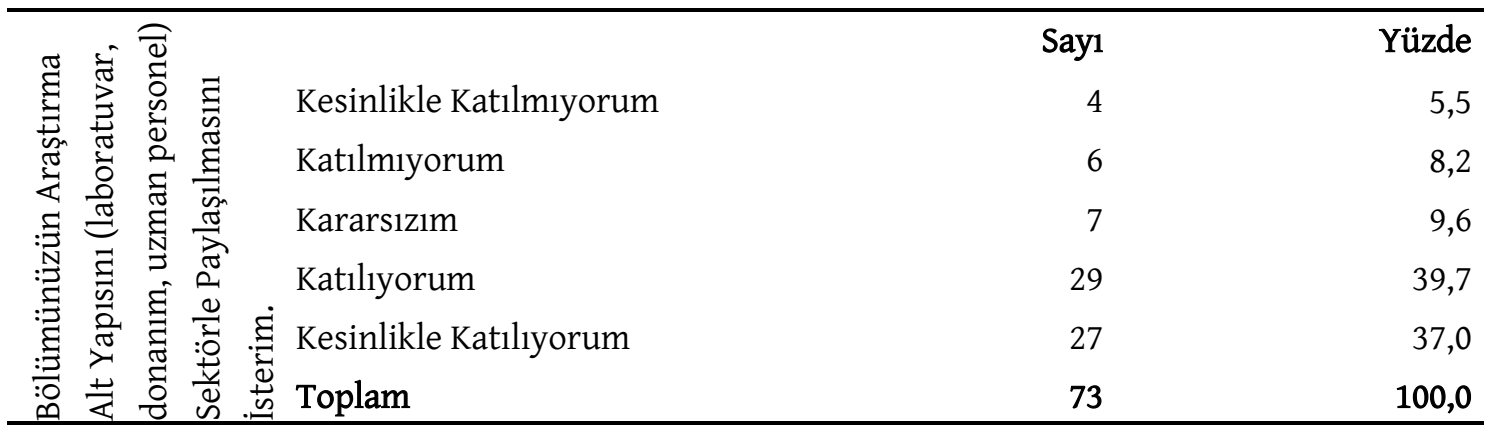

Tablo 2.16.'da görüldüğü gibi araştırmaya katılan olan örneklem grubunun, "Bölümünüzün araştırma alt yapısını sektörle paylaşılmasını isterim." sorusuna; \% 5,5’i (4 kişi) "Kesinlikle Katılmıyorum”, \% 8,2'si (6 kişi) “Katılmıyorum”, \% 9,6’si (7 kişi) “Kararsızım”, \% 39,7’si (29 kişi) “Katılıyorum”, \% 37,0’1 (27 kişi) “Kesinlikle Katıllyorum” cevabını vermiştir. Bu verilere göre yöneticilerin İlahiyat Fakültesinin sahip olduğu imkan ve kapasitesinden Erzincan İl MEM`e bağl1 okul ve kurumlarla paylaşılmasını istediklerini belirtmişlerdir. 
Tablo 2.17. Stajyer Öğretmenlerin İstihdamı Talebini Gösterir Dağılım

\begin{tabular}{|c|c|c|c|}
\hline \multirow{7}{*}{ 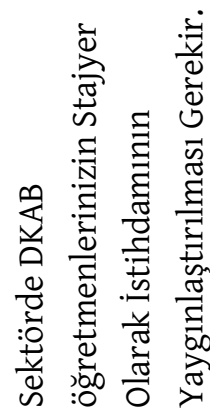 } & & Sayı & Yüzde \\
\hline & Kesinlikle Katılmiyorum & 2 & 2,7 \\
\hline & Katılmiyorum & 4 & 5,5 \\
\hline & Kararsızım & 6 & 8,2 \\
\hline & Katıliyorum & 37 & 50,7 \\
\hline & Kesinlikle Katılıyorum & 23 & 31,5 \\
\hline & Toplam & 73 & 100,0 \\
\hline
\end{tabular}

Tablo 2.17.'de görüldüğü gibi araştırmaya katılan olan örneklem grubunun, "Sektörde DKAB stajyer öğretmenlik uygulamasının yaygınlaştırılması gerekir.” sorusuna; \%2,7’si (2 kişi) “Kesinlikle Katılmıyorum”, \%5,5'i (4 kişi) “Katılmıyorum”, \%8,2'si (6 kişi) “Kararsızım”, \%50,7’si (37 kişi) "Katılıyorum”, \%31,5’i (23 kişi) "Kesinlikle Katılıyorum” cevabını vermiştir. Ayrıca katılımcıların \%1,4'ü (1 kişi) bu soruya cevap vermemiştir. Elde edilen verilere göre, kurum yöneticileri İlahiyat Fakültesi bölümünden mezun olan DKAB öğretmen adaylarının deneyimlerinin artması bakımından stajyer olarak istihdamlarının yaygınlaştırılmasının gerekli olduğunu belirtmişlerdir.

Tablo 2.18. Bilgi Deneyim Paylaşımı Talebini Gösterir Dağılım

\begin{tabular}{|c|c|c|c|}
\hline \multirow{7}{*}{ 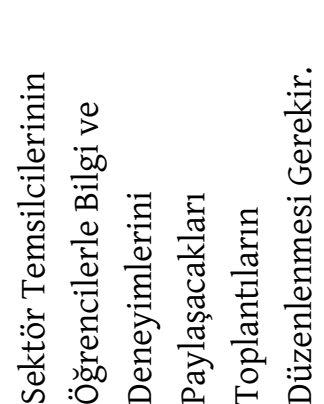 } & & Say1 & Yüzde \\
\hline & Kesinlikle Katılmıyorum & 3 & 4,1 \\
\hline & Katılmiyorum & 3 & 4,1 \\
\hline & Kararsızım & 3 & 4,1 \\
\hline & Katıliyorum & 38 & 52,1 \\
\hline & Kesinlikle Katılıyorum & 26 & 35,6 \\
\hline & Toplam & 73 & 100,0 \\
\hline
\end{tabular}

Tablo 2.18.'de görüldüğü gibi araştırmaya katılan olan örneklem grubunun, "Sektör temsilcilerinin öğrencilerle bilgi ve deneyimlerini paylaşacakları toplantıların düzenlenmesi gerekir." sorusuna; \%4,1'i (3 kişi) “Kesinlikle Katılmıyorum”, \%4,1'i (3 kişi) “Katılmıyorum”, \%4,1’i (3 kişi) “Kararsızım”, \%52,1'i (38 kişi) “Katılıyorum”, \%35,6'sı (26 kişi) “Kesinlikle Katılıyorum” cevabını vermiştir. Elde edilen verilere göre, İlahiyat Fakültesi bölümünden mezun olan ve alanda çalışan yönetici ve DKAB öğretmenlerinin, hali hazırda ilahiyat fakültesinde okuyan ve geleceğin potansiyel öğretmen adayları olan öğrencilerle bilgi ve deneyimlerini paylaşacakları toplantıların düzenlenmesi gerektiği bulunmuştur. 
Tablo 2.19. Kariyer Günleri Düzenlenmesini Gösterir Dağllım

\begin{tabular}{|c|c|c|c|}
\hline \multirow{7}{*}{ 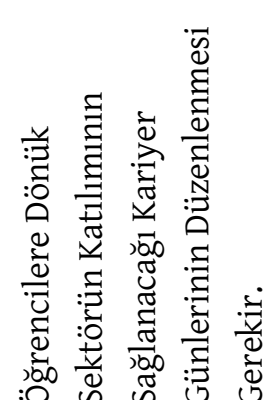 } & & Say1 & Yüzde \\
\hline & Kesinlikle Katılmıyorum & 3 & 4,1 \\
\hline & Katılmiyorum & 5 & 6,8 \\
\hline & Kararsızım & 8 & 11,0 \\
\hline & Katıliyorum & 28 & 38,4 \\
\hline & Kesinlikle Katılıyorum & 29 & 39,7 \\
\hline & Toplam & 73 & 100,0 \\
\hline
\end{tabular}

Tablo 2.19.'da görüldüğü gibi araștırmaya katılan olan örneklem grubunun, “Öğrencilere dönük sektörün katılımının sağlanacağı kariyer günlerinin düzenlenmesi gerekir." sorusuna; \%4,1’i (3 kişi) “Kesinlikle Katılmıyorum”, \%6,8’i (5 kişi) “Katılmıyorum”, \%11,0’ı (8 kişi) “Kararsızım”, \%38,4’ü (28 kişi) "Katılıyorum”, \%39,7'si (29 kişi) "Kesinlikle Katılıyorum” cevabını vermiştir. Elde edilen verilere göre, İlahiyat Fakültesi bölümünden mezun olan kişilerin katılımının sağlanacağı kariyer günlerinin düzenlenmesi gerekli olduğu bulunmuştur.

Tablo 2.20. Ders Planlarının Hazırlanmasına Katkı Talebini Gösterir Dağılım

\begin{tabular}{|c|c|c|c|}
\hline \multirow{7}{*}{ 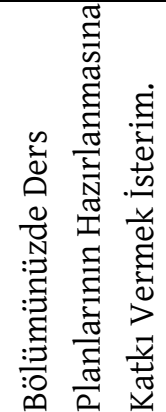 } & & Say1 & Yüzde \\
\hline & Kesinlikle Katılmıyorum & 2 & 2,7 \\
\hline & Katılmiyorum & 11 & 15,1 \\
\hline & Kararsızım & 20 & 27,4 \\
\hline & Katılıyorum & 28 & 38,4 \\
\hline & Kesinlikle Katılıyorum & 11 & 15,1 \\
\hline & Toplam & 73 & 100,0 \\
\hline
\end{tabular}

Tablo 2.20.'de görüldüğü gibi araştırmaya katılan olan örneklem grubunun, "Bölümünüzde ders planlarının hazırlanmasına katkı vermek isterim." sorusuna; \%2,7'si (2 kişi) "Kesinlikle Katılmıyorum”, \%15,1’i (11 kişi) “Katılmıyorum”, \%27,4’ü (20 kişi) “Kararsızım”, \%38,4’ü (28 kişi) "Katılıyorum”, \%15,1'i (11 kişi) "Kesinlikle Katılıyorum" cevabını vermiştir. Ayrıca katılımcıların \%1,4'ü (1 kişi) bu soruya cevap vermemiştir. Elde edilen verilere göre, Milli Eğitim Müdürlüğüne bağlı kurum yöneticilerin bölümlerinden mezun olan kişilerin kendi alanlarıyla ilgili ders planlarının hazırlanmasına katkı vermek istediklerini belirtmişlerdir. 
Tablo 2.21. Misafir Eğitici Olma Talebini Gösterir Dağılım

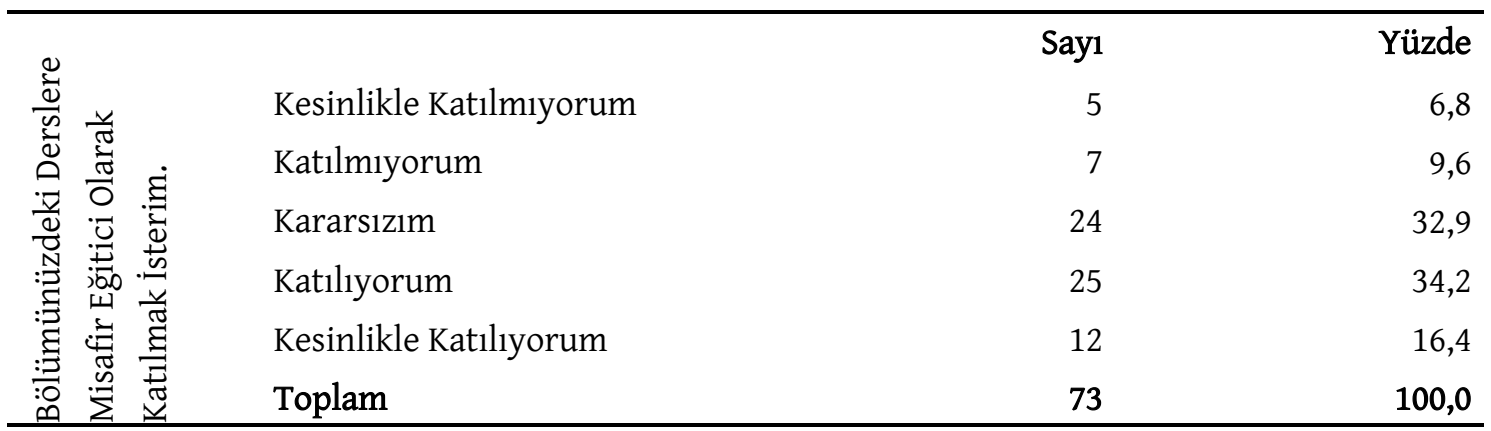

Tablo 2.21.'de görüldüğü gibi araştırmaya katılan olan örneklem grubunun, "Bölümünüzdeki derslere misafir eğitici olarak katılmak isterim." sorusuna; \%6,8'i (5 kişi) "Kesinlikle Katılmıyorum", \%9,6'si (7 kişi) “Katılmıyorum”, \%32,9'ü (24 kişi) "Kararsızım”, \%34,2'si (25 kişi) "Katıllyorum”, \%16,4'ü (12 kişi) “Kesinlikle Katılıyorum” cevabını vermiştir. Elde edilen verilere göre, kurum yöneticileri ilahiyat fakültesinde öğrencilerle deneyimlerini paylaşabilecekleri formasyon derslerine misafir eğitici olarak katılmak istediklerini belirtmişlerdir.

Tablo 2.22. Danışma Kurulunda Yer Alma İsteğini Gösterir Dağılım

\begin{tabular}{|c|c|c|c|}
\hline & & Say1 & Yüzde \\
\hline \multirow{6}{*}{ 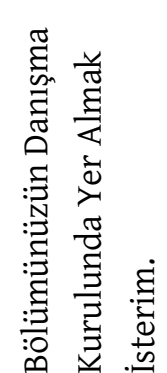 } & Kesinlikle Katılmıyorum & 2 & 2,7 \\
\hline & Katılmiyorum & 14 & 19,2 \\
\hline & Kararsızım & 21 & 28,8 \\
\hline & Katıliyorum & 26 & 35,6 \\
\hline & Kesinlikle Katıliyorum & 10 & 13,7 \\
\hline & Toplam & 73 & 100,0 \\
\hline
\end{tabular}

Tablo 22.'de görüldüğü gibi araştırmaya katılan olan örneklem grubunun, "Bölümünüzün danışma kurulunda yer almak isterim." sorusuna; \%2,7'si (2 kişi) “Kesinlikle Katılmıyorum”, \%19,2'si (14 kişi) “Katılmıyorum”, \%28,8’i (21 kişi) “Kararsızım”, \%35,6’si (26 kişi) “Katılıyorum”, \%13,7'si (10 kişi) "Kesinlikle Katılıyorum” cevabını vermiştir. Elde edilen verilere göre, kurum yöneticileri ilahiyat Fakültesinin danışma kurulunda yer almak istediklerini belirtmişlerdir.

\section{Tartı̧̧ma ve Sonuç}

İlahiyat fakülteleri, Millî Eğitim Bakanlığı ve Diyanet İşleri Başkanlığı başta olmak üzere birçok kuruma personel yetiştiren ve kurumların beklentilerini karşılamaya çalışan eğitim kurumlarıdır. ${ }^{15}$

\footnotetext{
${ }^{15}$ Habil Şentürk, “ỉlahiyatçıların Eğitim-Öğretimle İlgili (Mesleki) Genel Problemleri” (Yükseköğretimde Din Bilimleri Sempozyumu, Samsun: Ondokuz Mayıs Ünv. İlahiyat Fakültesi Yayınları, 1988), 114-119.
} 
$\mathrm{Bu}$ çalışmada İlahiyat Fakültelerinin vermiş olduğu eğitimin, Millî Eğitim Bakanlığına bağlı kurumların beklentilerini karşılayabilme noktasında hangi düzeyde olduğu ele alınmıştır. Elde edilen veriler Erzincan ilinde kurum yöneticilerine göre İlahiyat Fakültesi mezunlarının kurumdaki uygulamaları ile kurum/okul yöneticilerinin beklentilerini karşılayabildiği yönündedir. Ülkemizde yüksek öğretim kurumları içerisinde önemli bir yere sahip olan İlahiyat Fakülteleri, mezunlarını istihdam kurumların beklentilerini karşılayabilmek için alanında önder ve uzman din adamları yetiştirmeye çalışmaktadır.

$\mathrm{Bu}$ araştırmada Erzincan Üniversitesi tarafından hazırlanmış olan dış paydaş program değerlendirme anketi uygulanmıştır. Anket sonuçlarına göre, Erzincan ilinde çalışan kurumlardaki yöneticiler İlahiyat Fakültesi bölümünden mezun olan DKAB öğretmenlerinin sayısının sektörün ihtiyacını karşıladığı yönündedir. Günümüzde oldukça yaygınlaşan İlahiyat Fakültelerinin artık birçok üniversite de varlığı söz konusudur. ${ }^{16}$ Ayrıca bazı üniversitelerde Açık Öğretim Fakültesi'ne bağlı İlahiyat Ön lisans Programı ve İlahiyat Lisans Tamamlama (ILITAM) Programlarıyla alandaki din adamı ihtiyacı karşılanmaya çalışılmaktadır. ${ }^{17}$ İlahiyat Fakültesi eğitim programı alanında birçok araştırma yapılmıştır. Bazı araştırmalara göre lisans döneminde verilen eğitimin DKAB öğretmenlerinin mesleki bilgi açısından yeterli bulunmadığı yönündedir. ${ }^{18}$ Başka bir araştırmaya göre, toplumun ihtiyaçlarını ve beklentilerini karşılayabildiklerini fakat topluma daha üst bir hizmet sunabilmek için ilahiyat programlarının geliştirilerek daha iyi bir eğitim programından geçmesi gerektiği belirtilmiştir. ${ }^{19}$ Erzincan ilinde yapılan araştırmaya göre ise mezun olan DKAB öğretmenlerinin mesleki bilgi düzeylerinin yeterli olduğu bulunmuştur.

Geçmişe nazaran İlahiyat Fakültesi din eğitimi alanında kendini geliştirmeye çalışmış, lisans mezunlarına yönelik alanda program geliştirme çalışmaları, uzman kişilerin istihdam edilmesi ve

\footnotetext{
${ }^{16}$ Muzaffer Üzümcü, “İlahiyat Fakülteleri Felsefe ve Din Bilimleri Bölümlerinde Akademik Yapılanma ve Lisansüstü Eğitim Üzerine Bir Değerlendirme”, Mevzu - Sosyal Bilimler Dergisi 3 (15 Mart 2020), 167-192.

${ }^{17}$ Recep Kaymakcan vd., "Paydaşlarına Göre İlahiyat Lisans Tamamlama (ILİTAM) Programının Değerlendirilmesi”, Değerler Eğitimi Dergisi 11/26 (01 Aralık 2013), 71-110.

${ }^{18}$ Nevzat Yaşar Aşıkoğlu, “ỉlahiyat Fakültelerinin Eğitim Öğretime Katkıları ve Kaliteye Yolculuk”, Cumhuriyet Üniversitesi İlahiyat Fakültesi Dergisi 9/1 (15 Haziran 2005), 1-10; Saadettin Özdemir, "Diyanet Hizmetleri Açısından İlahiyat Fakültesi Program(lar)1”, Din ve Bilim - Muş Alparslan Üniversitesi İslami İlimler Fakültesi Dergisi 2/1 (30 Haziran 2019), 1-25; Cihat Tunç, "Din Hizmetlerinde Görev Alacak İlahiyat Fakültesi Mezunlarının Yetiştirilmesi ve Sorunları. Türkiye'de Yüksek Din Eğitiminin Sorunları" (Türkiye'de Yüksek Din Eğitiminin Sorunları, Yeniden Yapılanması ve Geleceği Sempozyumu, Isparta, 2004).

${ }^{19}$ Gül, “Yüksek Din Eğitimi Kurumlarında Değişim ve Yenilenmenin Gerekçeleri”; Korukçu, "İlahiyat Fakültesi Son Sınıf Öğrencilerinin Yaygın Din Eğitimine Bakışları”; Özbek, "illahiyat fakültelerinde ilmî araştırma zihniyetinin geliştirilmesi.”; Varış, “Üniversitenin Değişen Fonksiyonu ve Birkaç Sorun”.
} 
formasyon programı yapılmaya çalışılmıştır. ${ }^{20}$ Din eğitimi alanında birçok çalışma yapılmış olmasına rağmen değişen ve gelişen çağın ihtiyaç ve beklentilerini karşılayabilmek için her zaman gelişim ve değişimler aktif bir şekilde takip edilmelidir. ${ }^{21}$ Din eğitimi alanında daha kaliteli, nitelikli ve toplumun beklentilerini karşılayabilmek için bu alandaki kuruluşların (İlahiyat Fakültesi, DỉB ve MEB) iş birliği içerisinde olması, ortak noktada buluşması ve birbirleriyle iletişim içerisinde toplumun ihtiyaç ve beklentilerini karşılamak için ortak hareket etmeleri gerekmektedir. Özdemir'e göre kuruluşların ortak hareket etmesiyle yapılacak olan program çeşitliliğinin hizmet kalitesini, verimliliğini ve memnuniyeti arttıracağı yönündedir. ${ }^{22}$

İlahiyat Fakültesinden mezun olan öğrencilerden kurumların mesleği ile ilgili beklentileri; kariyer ve sorumluluklarını yerine getiren, alanında yeterli bilgi ve beceriye sahip olan, duyarlı, bilinçli kimlik ve kişiliğe sahip bireylerin yetişmesi yönüdedir. Ayrıca üniversitelerinden mezun olan DKAB öğretmenlerinin iletişim ve sosyalleşme konusunda başarılı olmaları, alanlarıyla ilgili yeteneklerini geliştirmeleri, geçmiş bilgileri öğrenip yeni bilgileri içselleştirerek uygulayabilmesi ve mesleki alanda kendini geliştirmiş olması beklenmektedir. ${ }^{23}$ Elde edilen verilere göre Erzincan ilinde çalışan kurum yöneticilerinin, ilahiyat fakültesi mezunlarının alanlarıyla ilgili bilgi düzeyleri, iletişim, dil ve mesleki pratik becerilerinin yeterli olduğu bulunmuştur.

Eğitim dinamik bir kavramdır ve sürekli değişim ve gelişim içerisinde kendini yenilemektedir. Teknoloji çağında yaşayan insan artık tüm bilgilere kısa sürede ulaşabilmekte, internet üzerinden sosyalleşme ve etkileşim içerisinde bulunarak aralarında bilgiyi daha hızlı aktarabilmektedir. Eğitim- öğretim ve çalışma hayatı içinde teknoloji ve internet vazgeçilmez bir hal almıştır. Kurumlar teknolojiyi iyi kullanabilen aktif ve kendini iyi ifade edebilen kişileri talep etmektedir. Bu sebepten kişi mesleği ile ilgili kendini her açıdan geliştirmeli ve edindiği bilgiler doğrultusunda çözüm üretebilme becerisi kazanabilmeli ayrıca kendisinin de ürettiği çözümlerin bir parçası olduğunu unutmayıp her zaman öğrenen ve öğreten kimliğini aktif tutmaya çalışmalıdır. ${ }^{24} \mathrm{Bu}$ makalede İlahiyat Fakültesinde öğrenim görmüş ilahiyatçıların mesleği ile ilgili kariyer ve sorumlulukları irdelenmektedir. Özellikle çağımızda ortaya çıkan sorunlar karşısında ilahiyatçıya önemli görevler düştüğü hatırlatılmakta ve onun vazgeçilmez olduğuna işaret edilmektedir. İlahiyatçının mesleğini

\footnotetext{
${ }^{20}$ Adem Korukçu, “Yaygın Din Eğitiminde İlahiyat Fakültelerinin Yeri ve Önemi”, Değerler Eğitimi Dergisi 8/20 (01 Aralık 2010), 99-120.

${ }^{21}$ Kaymakcan vd., "Paydaşlarına Göre İlahiyat Lisans Tamamlama (ILITAM) Programının Değerlendirilmesi”.

${ }^{22}$ Özdemir, "Diyanet Hizmetleri Açısından İlahiyat Fakültesi Program(lar)ı”.

${ }^{23}$ Osman Zümrüt, "İlahiyat Fakültesi Mezunu (İlahiyatçı) Sorumluluğu”, Ondokuz Mayıs Üniversitesi İlahiyat Fakültesi Dergisi 23/23 (01 Haziran 2007), 9-22.

${ }^{24}$ Kaymakcan vd., "Paydaşlarına Göre İlahiyat Lisans Tamamlama (ILITAM) Programının Değerlendirilmesi”; Yavuz Ünal, "Modern Dönemde İlahiyat Eğitimi: Müfredat ve Yöntem Tartışmaları Üzerine Bir Değerlendirme” (Modern Dönemde İlahiyat Eğitimi, Müfredatı ve Yöntem Tartışmaları, Samsun: Ondokuz Mayıs Ünv. İlahiyat Fakültesi Yayınları, 2010), 19-32.
} 
severek ve onunla bütünleşerek icra etmesi gerektiği vurgulanmaktadır. ${ }^{25}$ Erzincan ilinde çalışan kurum yöneticileri verdiği cevaplara baktığımızda İlahiyat Fakültesi mezunlarının, çalıştıkları kurumlara alanlarıyla ilgili katkı sağlayabildikleri ve alanlarıyla ilgili aktif çalışmalar yaptıkları bulunmuştur.

Sonuç olarak, dış paydaş anketine göre ilahiyat fakültesi DKAB öğretmenlerinin üniversitelerinde almış olduğu mesleki becerilerin MEB Erzincan İl Milli Eğitim Müdürlüğü kurum yöneticilerini memnun ettiği ve beklentilerini karşıladığı şeklinde tespit edilmiştir. Fakat gelişmekte olan bir ülke olarak her alanda kendimizi geliştirmeye ve en üst seviyeye çıkarmaya çalıştı̆̆ımız gibi toplumumuzun temel taşı olan din eğitimi alanında da gelişen çağa ayak uydurmalı ve en üst seviyede hizmet vermeyi amaç edinmelidir.

\section{Kaynakça}

Aşıkoğlu, Nevzat Yaşar. "ilahiyat Fakültelerinin Eğitim Öğretime Katkıları ve Kaliteye Yolculuk”. Cumhuriyet Üniversitesi İlahiyat Fakültesi Dergisi 9/1 (15 Haziran 2005), 1-10.

Ayhan, Halis. “ílahiyat Fakültesi”. Dini Araştırmalar Dergisi 17 (1999), 19-39.

Gül, Ali Rıza. "Yüksek Din Eğitimi Kurumlarında Değişim ve Yenilenmenin Gerekçeleri”. Eskişehir Osmangazi Üniversitesi İlahiyat Fakültesi Dergisi 3/5 (15 Aralık 2016), 7-38.

Karasar, Niyazi. Bilimsel Araştırma Yöntemleri. Ankara: Nobel Yayın Dağıtım, 23. Basım, 2012.

Kaymakcan, Recep vd. "Paydaşlarına Göre İlahiyat Lisans Tamamlama (ILİTAM) Programının Değerlendirilmesi”. Değerler Eğitimi Dergisi 11/26 (01 Aralık 2013), 71-110.

Korkmaz, Mehmet. “ílahiyat Fakültelerinin Yaygın Din Eğitimi Yeterlikleri: Eğitim-Öğretim Alanı”. Değerler Eğitimi Dergisi 10/24 (01 Aralık 2012), 127-146.

Korukçu, Adem. “ỉlahiyat Fakültesi Son Sınıf Öğrencilerinin Yaygın Din Eğitimine Bakışları”. Değerler Eğitimi Dergisi 9/21 (01 Haziran 2011), 55-97.

Korukçu, Adem. "Yaygın Din Eğitiminde İlahiyat Fakültelerinin Yeri ve Önemi”. Değerler Eğitimi Dergisi 8/20 (01 Aralık 2010), 99-120.

\footnotetext{
${ }^{25}$ Zümrüt, “İlahiyat Fakültesi Mezunu (İlahiyatçı) Sorumluluğu”.
} 
Göksu-Güven, Expectations of Institutional Administrators Working in the Ministry of National Education from the Graduates

Okumuş, Ejder. “illahiyat Fakültesi Öğrencilerinin Problemleri - Dicle Üniversitesi Örneği -”. Değerler Eğitimi Dergisi 5/13 (01 Haziran 2007), 59-94.

Osmanoglu, Cemil - Korkmaz, Mehmet. "Öğrencilerine Göre İdeal İlahiyat Fakültesi Öğrencisinin Nitelikleri ve Bunların İlahiyat Eğitimiyle İlişkisi”. Değerler Eğitimi Dergisi 16/36 (2018), 119178.

Özbek, Abdullah. “ỉlahiyat fakültelerinde ilmî araştırma zihniyetinin geliştirilmesi.” 45-53. Samsun: Ondokuz Mayıs Ünv. İlahiyat Fakültesi Yayınları, 1988.

Özdemir, Saadettin. "Diyanet Hizmetleri Açısından İlahiyat Fakültesi Program(lar)1". Din ve Bilim Muş Alparslan Üniversitesi İslami İlimler Fakültesi Dergisi 2/1 (30 Haziran 2019), 1-25.

Özenç, Ali. "Son Sınıf Öğrencilerine Göre Beklentileri Karşılama ve Mesleki Hayata Hazırlamada İlahiyat Fakültelerinde Eğitim (Dicle Üniversitesi Örneği)". International Journal of Kurdish Studies 3/1 (25 Ocak 2017), 1-30. https://doi.org/10.21600/ijoks.288954

Şentürk, Habil. “İlahiyatçıların Eğitim-Öğretimle İlgili (Mesleki) Genel Problemleri”. 114-119. Samsun: Ondokuz Mayıs Ünv. İlahiyat Fakültesi Yayınları, 1988.

Tunç, Cihat. "Din Hizmetlerinde Görev Alacak İlahiyat Fakültesi Mezunlarının Yetiştirilmesi ve Sorunları. Türkiye'de Yüksek Din Eğitiminin Sorunları”. Isparta, 2004.

Turan, İbrahim. "Din Görevlilerinin Mesleki Yeterlilikleri”. Dinbilimleri Akademik Araştırma Dergisi 13/3 (01 Haziran 2013), 47-73.

Ünal, Yavuz. "Modern Dönemde İlahiyat Eğitimi: Müfredat ve Yöntem Tartışmaları Üzerine Bir Değerlendirme". 19-32. Samsun: Ondokuz Mayıs Ünv. İlahiyat Fakültesi Yayınları, 2010.

Üzümcü, Muzaffer. "İlahiyat Fakülteleri Felsefe ve Din Bilimleri Bölümlerinde Akademik Yapılanma ve Lisansüstü Eğitim Üzerine Bir Değerlendirme”. Mevzu - Sosyal Bilimler Dergisi 3 (15 Mart 2020), 167-192. https://doi.org/10.5281/zenodo.3710818

Varış, Fatma. “Üniversitenin Değişen Fonksiyonu ve Birkaç Sorun”. Ankara Üniversitesi Eğitim Bilimleri Fakültesi Dergisi 7/1 (12 Eylül 2019), 345-360. https://doi.org/10.1501/Egifak_0000000416

Zümrüt, Osman. "İlahiyat Fakültesi Mezunu (İlahiyatçı) Sorumluluğu”. Ondokuz Mayıs Üniversitesi Illahiyat Fakültesi Dergisi 23/23 (01 Haziran 2007), 9-22. https://doi.org/10.17120/omuifd.08699

Expectations of Institutional Administrators Working in the Ministry of National Education from the Graduates of the Faculty of Theology: The Sample of Erzincan 
Asst. Prof. Dr. M. Zeki GÖKSU - Hülya GÜVEN

\section{Extended Abstract}

Education is one of the essential factors in the change and development of societies. (Ayhan 1999) As people become more informed during the education process, they affect the environment and society they live in and change. (Okumuş 2007). The primary purpose of education is to raise knowledgeable, mature, and qualified people who have improved themselves in their field. (Korkmaz 2012). Because of this need, an education model has been created by considering each society's cultural values, social and individual needs, and universal changes. This education model has been tried to be prepared considering the needs and orientations of the society and the individual and the interests, needs, and expectations of the individuals. According to certain education models in our country, individuals are educated in schools (Osmanoğlu - Korkmaz,2018). In line with these pieces of training, it is expected from individuals that they can reflect the training they have received to the society and their lives at a fair level.

The concept of "religious education", which is the main subject of society, is one of these education areas. Religious education is first given by parents and then by environmental and educational institutions. A person lays the foundations on religion and morality within the scope of religious culture and ethics in primary, secondary, and high school life. Teachers/instructors teaching in these schools professionally transfer their professional expertise to DKAB (religious culture and ethics) teachers. Faculties of Islamic Sciences/Theology, which train experts in religious education, are the most important institutions of our time (Korukçu 2011; Özbek 1988).

The subject we will discuss in our article will be discussed through the question "What is the satisfaction level of the institutions/school administrators working in the Erzincan Provincial Directorate of National Education and its affiliated schools from the professional practices of DKAB Teachers graduated from the Faculty of Theology?" According to research conducted on this subject, it was stated that theology faculties are institutions that have developed in their field and that try to improve themselves by adapting to changing educational standards. However, it has been stated that the changes in these education programs are not sufficient and that change and development are necessary in order to meet the needs and expectations of our society in order to compete in the international arena, to eliminate the negative results of the uniform education in our education system, and to determine strategies for a better education system (Gül 2016). Institutions such as the Ministry of National Education and the Presidency of Religious Affairs, which employ graduates of the Faculty of Theology, have some expectations from those who graduated from the university and started their working life. 
In this study, the level of satisfaction and expectations of the institution managers regarding professional competence perceptions, content knowledge, skills, and application competencies of DKAB teachers who graduated from the Faculty of Theology working in the Ministry of National Education was examined.

Our study aims to meet the satisfaction levels and expectations of the administrators of the Erzincan Provincial Directorate of National Education, which is one of the provincial organizations of the Ministry of National Education, and the administrators of the Basic Education and Secondary Education Institutions working under the Erzincan Provincial Directorate of National Education, from the Religious Culture Ethics teachers who graduated from the Faculty of Theology and to determine whether they meet the satisfaction levels and expectations.

2019-2020 academic year, 12.3\% (9 people) of Faculty of Theology graduates in Erzincan province, branch managers working in Erzincan Provincial Directorate of National Education, $41.1 \%$ (34 people) Basic Education (Secondary School),\% It was obtained from a total of 73 male institution managers, 46.6 (30 people) working in secondary education institutions. It can be said that this number represents the universe when the total number of institution managers working in Erzincan province in the previous academic year (9 branch managers, 59 secondary school managers/assistant principals, 49 high school managers / assistant principals in total 117 people).

A single scanning model was used in the study. The research is a study conducted with the participation of 73 volunteer administrators working in Erzincan Provincial Directorate of National Education and its affiliated schools. For this study by the researcher, the participants answered a 22-question external stakeholder evaluation questionnaire and a 6-question personal information form to reveal their demographic characteristics. In the analysis part of the research, the frequency and percentage distributions of the findings obtained from the questionnaire were analyzed with the SPSS 20.0 (Statistical Packagefor Social Science) statistical package program. The obtained data were interpreted by turning them into tables.

According to the institution managers working in the Erzincan Provincial Directorate of National Education and its affiliated schools;

1- The education received by DKAB teachers who graduated from theology can meet the expectations.

2- The number of graduates given by theology faculties meets the needs of institutions and schools affiliated with the Ministry of National Education.

3- DKAB teachers who graduated from the faculty of theology are considered sufficient in terms of professional knowledge. 
4- DKAB teachers who are graduates of theology faculty can meet the expectations regarding their communication skills and professional competencies.

5- DKAB teachers who are graduates of theology faculty can contribute to the institutions they work in related to their fields.

Interpretations of the results of the analysis of the data obtained for the research are included.

Frequency and percentage distributions of the participants according to gender, age, marital status, department, professional seniority, and type of work are given in tables.

Frequency and percentage distributions of the answers given by the participants to the external stakeholder survey are given in tables.

In this study, it is discussed at what level the education given by the Faculties of Theology is at the point of meeting the expectations of the institutions affiliated with the Ministry of National Education. According to the administrators of the institutions in Erzincan, the obtained data show that the graduates of the Faculty of Theology can meet the expectations of the institution/school administrators with their practices in the institution. As a result, according to the external stakeholder survey, it was determined that the vocational skills of theology faculty DKAB teachers at their universities satisfied the institution administrators of the MEB Erzincan Provincial Directorate of National Education and met their expectations. However, as a developing country, It is tryed to improve and maximize ourselves in every field. We must keep up with the developing age in religious education, which is the cornerstone of our society, and aim to serve at the highest level.

Keywords: Religious Education, Ministry of National Education, Faculty of Theology, Expectation, Satisfaction. 
Göksu-Güven, Expectations of Institutional Administrators Working in the Ministry of National Education from the Graduates 